\title{
STUDI PENELUSURAN (TRACER STUDY) TERHADAP ALUMNI PROGRAM STUDI PENDIDIKAN TEKNIK INFORMATIKA JURUSAN PENDIDIKAN TEKNIK ELEKTRONIKA FAKULTAS TEKNIK UNIVERSITAS NEGERI YOGYAKARTA
}

\author{
Nuryake Fajaryati $^{1}$, Priyanto $^{2}$, Totok Sukardiyono ${ }^{3}$, Athika Dwi Wiji Utami ${ }^{4}$, \\ Sigit Pambudi ${ }^{5}$, Bonita Destiana ${ }^{6}$ \\ Jurusan Pendidikan Teknik Elektronika FT UNY \\ nuryake@uny.ac.id
}

\begin{abstract}
ABSTRAK
Penelitian tracer study ini bertujuan untuk memperoleh gambaran lama masa tunggu alumni sampai mendapatkan pekerjaan, mendeskripsikan penilaian alumni mengenai penyelenggaraan dan mutu layanan program yang ada di Program Studi Pendidikan Teknik Informatika FT UNY dan mendeskripsikan penilaian pengguna alumni terhadap kompetensi lulusan Pendidikan Teknik Informatika FT UNY. Penelitian ini termasuk jenis penelitian deskriptif kualitatif (qualitative research) melalui pendekatan survei mencakup tiga tahapan: 1) pengembangan konsep dan instrumen; 2) pengumpulan data; dan 3) analisa data dan pelaporan. Metode sampling dengan cara random, dengan proporsi $30 \%$ secara proporsional sesuai dengan jumlah lulusan. Jenis data yang dikumpulkan dalam penelitian ini adalah data primer yang diperoleh langsung dari alumni dan pengguna alumni melalui kuesioner yang terstruktur. Penyebaran kuesioner dilakukan secara online melalui Google docs dan penyebaran secara langsung kepada alumni atau pengguna alumni yang diketahui dengan jelas keberadaannya. Pengumpulan data lapangan dimulai pada Mei 2015 hingga Agustus 2015.Hasil penelitian menunjukkan sebagian besar alumni Program Studi Pendidikan Teknik Informatika mendapatkan pekerjaan dengan masa tunggu kurang dari 6 bulan yaitu sebanyak $88 \%$, sementara lainnya membutuhkan waktu selama lebih dari 18 bulan sebanyak 7\%, rentang 6 - 12 bulan sebanyak 3\%, dan rentang 13 - 18 bulan sebanyak 2\%. Mengenai penyelenggaraan dan mutu layanan, alumni memberikan penilaian baik dari persepsi semua aspek, namun dibutuhkan peningkatan dari segi SDM maupun fasilitas sarana dan prasarana. Pengguna alumni menilai bahwa kompetensi lulusan Program Studi Pendidikan Teknik Informatika dari segi aspek integritas, profesionalisme, penggunaan TI, komunikasi, kerjasama tim, dan pengembangan diri sangat baik, namun masih kurang dalam penggunaan bahasa, khususnya bahasa Inggris.
\end{abstract}

Kata Kunci : tracer study, Pendidikan Teknik Informatika, alumni

\section{PENDAHULUAN}

Perguruan tinggi sebagai pihak penyelenggara pendidikan tinggi mempunyai peran serta yang sangat penting dalam mencerdaskan bangsa, khususnya diharapkan dapat menghasilkan lulusan-lulusan berkualitas yang siap kerja maupun siap menciptakan lapangan kerja di masyarakat. Seberapa besar lulusan perguruan tinggi mampu berkiprah dalam pembangunan sesuai relevansi pendidikannya dapat dilakukan upaya penelusuran terhadap lulusannya (tracer study).

Tracer study merupakan studi yang tujuan utamanya untuk memperoleh informasi mengenai lulusan yang sudah bekerja dan belum bekerja. Selain itu tracer study bertujuan untuk mengetahui hasil pendidikan dalam bentuk penguasaan dan pemerolehan kompetensi lulusan yang diaplikasikan di dunia kerja serta transisi dari dunia pendidikan tinggi ke dunia usaha dan industri. Melalui tracer study ini penyelenggara pendidikan dapat mengetahui bagaimana penyelenggaraan dan mutu layanan program melalui penilaian para alumni. Melalui ini maka penyelenggara pendidikan mampu untuk memperbaiki dan meningkatkan kualitas layanannya.

Secara kelembagaan selain untuk memperoleh informasi penting berupa umpan 
balik alumni sebagai bahan evaluasi untuk mengetahui relevansi pendidikan tinggi dengan pekerjaan, lembaga pendidikan juga ditagih oleh stakeholders tentang kiprah nyata mencerdaskan generasi bangsa dalam wujud melahirkan lulusan yang berkualitas secara akademis maupun yang anggun kepribadiannya. Untuk melaksanakan cita-cita mulia tersebut, lembaga pendidikan dituntut untuk terus mereorganisasi dirinya dan meningkatkan kualitas layanan pendidikan kepada publik. Salah satunya melalui penilaian kinerja program studi oleh Badan Akreditasi Nasional Perguruan Tinggi (BAN PT) dan penyusunan laporan Evaluasi Diri sebagai dasar pijakan konsolidasi organisasi dan pengembangan program kegiatan akademik. Salah satu butir evaluasi diri dan isian borang akreditasi ialah mengenai keberadaan lulusan setelah meninggalkan bangku kuliah.

Ada tiga manfaat yang bisa diperoleh dari pelaksanaan tracer study, yaitu: 1) mengetahui kepuasan stakeholder, dalam hal ini lulusan, terkait dengan learning experiences yang mereka alami, untuk dijadikan alat evaluasi kinerja institusi; 2) mendapatkan masukan yang relevan sebagai dasar pijakan pengembangan institusi, terkait dengan kemampuan bersaing, kualitas, dan working experiences lulusan yang bisa digunakan untuk menangkap kesempatan dan menanggulangi ancaman ke depan; 3) meningkatkan hubungan lulusan dan almamater, karena apabila dilihat dari pengalaman institusi-institusi pendidikan terkenal, ikatan lulusan dan almamater yang kuat akan banyak membawa banyak manfaat kepada almamater seiring dengan diakuinya kiprah lulusan di masyarakat. (Soemantri, 2010: 4)

Lebih lanjut, tujuan Tracer study dalam penelitian ini adalah untuk mengukur dan melacak kinerja lulusan sehingga dapat diperoleh indikator yang jelas tentang profil lulusan dari Program Studi Pendidikan Teknik Informatika terutama selama kurun 2007 sampai dengan 2010. Profil lulusan ini setidaknya meliputi tiga hal yang diperlukan syarat akreditasi yaitu masa tunggu lulusan, persentase lulusan yang sudah bekerja, dan kompetensi lulusan.

Berdasarkan uraian di atas, penelitian ini akan melakukan studi penelusuran pada lulusan mahasiswa Program Studi Pendidikan Teknik Informatika selama kurun 2007 sampai dengan 2010 dengan tujuan untuk: 1) memperoleh gambaran mengenai penilaian alumni mengenai penyelenggaraan dan mutu layanan program yang ada di Program Studi Pendidikan Teknik Informatika FT UNY; 2) mengetahui bagaimana penilaian pengguna alumni terhadap kompetensi lulusan Pendidikan Teknik Informatika FT UNY; dan 3) kontribusi dalam proses akreditasi program studi. Hal tersebut dilakukan dalam usaha untuk meningkatkan kualitas penyelenggaraan dan mutu layanan program serta kompetensi lulusan Program Studi Pendidikan Teknik Informatika, Fakultas Teknik, Universitas Negeri Yogyakarta.

\section{METODE}

Penelitian ini termasuk jenis penelitian deskriptif kuantitatif melalui pendekatan survei. Secara umum, pelaksanaan tracer study ini mencakup tiga langkah berikut: 1) pengembangan konsep dan instrumen; 2) pengumpulan data; serta 3) analisa data dan pelaporan. Penelitian ini bertujuan mendeskripsikan penilaian alumni terhadap penyelenggaraan dan kualitas mutu layanan program, penilaian pengguna alumni terhadap kompetensi lulusan Program Studi Pendidikan Teknik Informatika serta masa tunggu alumni sampai mendapat pekerjaan. 


\section{HASIL DAN PEMBAHASAN}

\section{Profil Alumni Prodi PTI}

Dari hasil studi penelusuran diperoleh kondisi alumni sebagai berikut: 1) IPK rata-rata alumni adalah 3,48. 2) Lama masa studi ratarata alumni adalah 4 tahun 7 bulan. 3) Pekerjaan yang ditekuni sebagian besar adalah sebagai karyawan di perusahan pengembang TI (IT developer) dan tenaga pendidik baik di perguruan tinggi maupun sekolah menengah kejuruan. 5) Lama masa tunggu sebagian besar alumni dalam memperoleh pekerjaan pertama kurang dari 6 bulan. 6) Rerata gaji pertama yang diperoleh pada kisaran 1-3 juta rupiah.

\section{Penilaian Alumni terhadap Penyeleng- garaan dan Mutu Layanan}

Penilaian alumni terhadap

penyelenggaraan dan mutu layanan di prodi PTI dilihat dari persepsi alumni pada aspek: 1) layanan administrasi, 2) aspek pembelajaran, 3) fasilitas prodi, dan 4) pengalaman belajar.

Pada aspek layanan administrasi yang meliputi efektivitas layanan, kecepatan penyelesaian berkas, kemampuan komunikasi petugas, dan keramahan dalam pelayanan sudah baik. Pada aspek proses pembelajaran yang meliputi interaksi dosen dengan mahasiswa, proses pembelajaran di kelas, praktikum serta penulisan riset sudah baik. Hal tersebut diperlihatkan dari perolehan nilai pencapaian kualitas sebesar 69\%. Sebagian alumni merasakan bahwa prodi telah memberi kemudahan dalam pelayanan administrasi dan proses belajar mengajar.

Pada aspek pembelajaran perolehan nilai pencapaian kualitas persepsi kepuasan alumni sebesar $69 \%$ dalam kategori baik, tentunya akan lebih baik apabila ditingkatkan. Sedangkan pada aspek fasilitas prodi nilai kepuasan alumni mencapai 73\%. Responden merasa mutu pelayanan sudah cukup akan tetapi membutuhkan peningkatan dari segi Sumber Daya Manusia (SDM) maupun fasilitas sarana dan prasarana sehingga mutu dapat bersaing dengan universitas lain dan output mahasiswa dapat bersaing di dunia.

Pada aspek penilaian alumni pada pengalaman belajar di luar PBM memperoleh nilai pencapaian kualitas persepsi kepuasan sebesar 72\%. Hal ini menunjukkan bahwa pengalaman belajar alumni yang diperoleh dari kegiatan-kegiatan selama studi seperti magang/praktek industri, kunjungan industri, kegiatan extrakurikuler, dan kegiatan organisasi kemahasiswaan sanggup membekali alumni di dunia kerja. Alumni juga memberikan masukan untuk lebih meningkatkan pengembangan dan bimbingan karir, diantaranya melalui kerjasama atau membangun mitra kerja dari perusahaan lain untuk mulai merekrut lulusan Prodi Pendidikan Teknik Informatika sehingga lulusan akan lebih mudah dalam mencari pekerjaan, tidak hanya sebagai guru namun juga sebagai karyawan swasta di perusahaan yang dapat melibatkan alumni yang sudah terlibat langsung di Dunia Usaha dan Dunia Industri (DUDI).

Hasil penilaian alumni terhadap penyelenggaraan dan mutu layanan di prodi PTI secara keseluruhan dapat dilihat pada tabel berikut:

Tabel 1. Tabel Penilaian Alumni terhadap Mutu Layanan Prodi PTI

\begin{tabular}{lcc}
\hline \multicolumn{1}{c}{ Aspek } & Persentase & Kategori \\
\hline Layanan administrasi & $69 \%$ & Baik \\
\hline Pembelajaran & $69 \%$ & Baik \\
\hline Fasilitas prodi & $73 \%$ & Baik \\
\hline Pengalaman belajar & $72 \%$ & Baik \\
\hline
\end{tabular}

\section{Penilaian Pengguna Alumni terhadap Kompetensi Lulusan}

Persepsi pengguna terhadap kompetensi alumni Prodi Pendidikan Teknik Informatika selain diperoleh dari responden sekolah dan perusahan tempat alumni bekerja. Aspek yang dinilai diantaranya: 1) integritas, 2) profesionalisme, 3) penggunaan bahasa, 4) penggunaan TI, 
5) komunikasi, 6) kerjasama tim, dan 7) pengembangan diri.

Pada aspek kemampuan kerja, pengguna alumni di sekolah merasakan bahwa tingkat integritas, profesionalisme, penggunaan TI, komunikasi, kerjasama tim, dan pengembangan diri sangat baik. Hal tersebut menunjukkan bahwa alumni Prodi Pendidikan Teknik Informatika dapat mengaplikasikan kompetensi yang diperoleh selama perkuliahan dan menempatkan posisi dimana alumni bekerja.

Berdasarkan persepsi responden di perusahan diperoleh sedikit kekurangan yang diharapkan dapat menjadi masukan bagi Prodi Pendidikan Teknik Informatika, yakni penggunaan bahasa khususnya bahasa inggris di perusahaan masih perlu ditingkatkan. Responden juga menambahkan bahwa alumni Prodi Pendidikan Teknik Informatika sudah memiliki semangat kerja dan kompetensi yang baik, namun perlu meningkatkan kemampuan dalam berbahasa inggris karena perusahan di bidang TI sangat erat kaitannya dengan dunia internasional. Selain itu, kerjasama dengan rekan kerja yang lain juga perlu ditingkatkan hal ini diperlukan supaya antar tim dapat saling melakukan transfer knowledge.

\section{SIMPULAN}

Berdasarkan hasil penelitian dan pembahasan, maka diperoleh kesimpulan sebagai berikut: 1) Berdasarkan data, sebagian besar alumni Program Studi Pendidikan Teknik Informatika mendapatkan pekerjaan dengan masa tunggu kurang dari 6 bulan yaitu sebanyak $88 \%$, sementara lainnya membutuhkan waktu selama lebih dari 18 bulan sebanyak $7 \%$, rentang 6-12 bulan sebanyak 3\%, dan rentang 13-18 bulan sebanyak $2 \%$. 2) Penilaian alumni mengenai penyelenggaraaan dan mutu layanan ini merupakan pendapat dari alumni tentang sistem yang ada di prodi pendidikan teknik Informatika. Berdasarkan data yang diperoleh, alumni memberikan penilaian baik dari persepsi semua aspek yaitu: layanan administrasi, aspek pembelajaran, aspek fasilitas Program Studi, dan aspek pengalaman belajar. Namun alumni merasa mutu pelayanan membutuhkan peningkatan dari segi SDM maupun fasilitas sarana dan prasarana sehingga dapat bersaing dengan universitas lain dan output mahasiswa dapat bersaing di dunia. 3) Pengguna alumni menilai bahwa kompetensi lulusan Pendidikan Teknik Informatika dari segi aspek integritas, profesionalisme, penggunaan TI, komunikasi, kerjasama tim, dan pengembangan diri sangat baik. Hal tersebut menunjukkan bahwa alumni prodi Pendidikan Teknik Informatika dapat mengaplikasikan kompetensi yang diperoleh selama kuliah. Adapun aspek yang dinilai masih kurang dan perlu ditingkatkan, yaitu penggunaan bahasa, khususnya bahasa Inggris.

\section{DAFTAR RUJUKAN}

Anonim. 2002. Bahan Pelatihan Metode Pelaksanaan Studi Pelacakan. Jakarta: Depdiknas-ADB.

Cascio, W F., dan Awad. 1981. Human resources management : an information system approach. Virginia : reston publishing company.

Departemen Pendidikan Nasional. 2002. Kamus besar bahasa indonesia. PT. Gramedia Pustaka Utama. Jakarta.

Dhyah Setyotini,dkk. 2012. Kajian relevansi kemampuan penguasaan bahasa asing dan teknologi informasi lulusan prodi akuntasi FE UNY. Yogyakarta

John M. Echols dan Hasan Shadily. 2014. Kamus inggris-indonesia. PT. Gramedia Pustaka Utama. Jakarta.

Marwata, 2009. Eksistensi perguruan tinggi swasta. Diunduh dari http://cetak.kompas.com/read/2009/1 
0/14/11011932/eksistensi.perguruan.t inggi.swasta.

Moh. Nazir. 1999. Metode penelitian. Jakarta : Ghalia Indonesia.

Rasiman, dkk. 2008. Penelusuran lulusan Program STudi Pendidikan Matematika IKIP PGRI Semarang melalui Studi Pelacakan (Tracer Study) Sebagai Umpan Balik Penyempurnaan Kurikulum Tahun 2008. Jurnal Media Penelitian Pendidikan, (online), Vol.2 No. 2,

(http://www.academia.edu/1939473/penelu suran_lulusan program studi pendid ikan_matematika ikip_pgri_semaran g melalui studi pelacakan tracer st udy sebagai, diakses 28 Desember 2015)

Robbins, Stephen dan Judge, Timoth A. 2007. Organizational behaviour ${ }^{12 \mathrm{nd}}$
Edition. New Jersey : Upper Saddle River.

Setiawan Bambang \& Ahmad Muntaha. 2000. Metode penelitian komunikasi II. Jakarta: Universitas Terbuka.

Schomburg, Harald. 2003. Handbook for Graduate Tracer Studies: Centre for Research on Higher Education and Work, University of Kassel, Germany. Diunduh dari http://www.qtafi.de/handbook v2.pdf.

SEARCA. 2008. Tracer Study on SEARCA Fellows and UC Grantees. http://aau.org/studyprogram/web/sch olarship. 24 Agustus 2008

Soemantri, dkk. 2010. Kajian Relevansi Lulusan Jurusan Pendidikan Geografi Uny Tahun 2005 - 2009. Yogyakarta: FISE UNY. 